\title{
The Voice of a Woman: A Life Journey. An Islamic Feminist Reading of The Book of Fate
}

\author{
Prof. Nayera Ahmad El-Miniawi \\ AlBalqa' Applied University, \\ P.O. B. 206, Salt 19117, Jordan; \\ Princess Alia University College, \\ Abu Hamed Al Ghazali St 15, Amman, Jordan
}

DOI: https://doi.org/10.36941/jesr-2021-0020

\begin{abstract}
The Book of Fate is a novel that spans over fifty years of the life of the protagonist, Massoumeh, an Iranian girl/woman from a middle-class, religious Muslim family, who is forcefully and hastily married to a complete stranger after her family finds out that she was having an innocent love relationship with a young pharmacist assistant. The narrative follows her struggle to get an education and a job, and to look after her children as a single mother. The book portrays the oppressive conditions that women can suffer from in an oppressive patriarchal Islamic society. The novel surveys a lifetime of endurance and survival. Actually, her seeming feminine weakness is only one side of the coin. Her weakness is transformed, when required, into strength and accomplishments like the legendary Phoenix that is burnt up but out of the ashes springs a new life, metaphorically announcing resilience and fortitude.
\end{abstract}

Keywords: life journey; feminism; gender power game; Islamic feminism; patriarchal Muslim society; women's weakness and strength

\section{Introduction}

The purpose of this paper is to examine how the female novelist, Parinoush Sniee, has developed a bestselling novel that depicts the life journey of a woman in an unjust and abusive Oriental patriarchal society. This journey starts from her early formative childhood years and continues through different stages of growth and suffering, ending in her later years of maturity (bildungsroman, i.e., a coming-ofage novel).

This analysis is proposed to be done in the light of a critical feminist approach with special focus on Islamic Feminism as the events take place in a conservative Muslim society. The examination of the literary work will be done in the light of different methods of literary criticism, namely: close reading, social, historical, psychological and feminist approaches of criticism.

The paper will attempt to answer the questions of how and why a woman suffers, and what types of challenges she can possibly meet, within the framework of a family saga, in such a society. What does a woman feel and how does she react when faced with such unfairness and gender discrimination in such an environment because of certain customs, traditions and religious beliefs? Are men always abusive and victimizers? And are women generally meek victims, or are these roles sometimes altered 
and reversed?

The literary analysis will survey women, not only in their weakness and submission, but also in their moments of strength and resourcefulness. What tactics and resources does the victim use to survive? Some measures that can be employed are: sisterhood, education, silence, tears, passive acceptance or active resistance, slyness, pleasantness or breaking the norms. These will be points of examination and analysis.

The paper will examine and analyze how such fight-back tactics might defy the stereotyping of women, and also the stereotyping of the general traits of each gender. It will explore if the victim is always a female, and the victimizer, a male. Could it be that some women victimize other women, and some men are victims of the same patriarchal society and its dictates?

How is this "game of power" portrayed, and how does it control people's fate in the novel entitled The Book of Fate?

\section{Biographical Notes on the Author}

Parinoush Saniee is an Iranian woman, a social researcher, sociologist and psychologist. She has chosen to put the data she has compiled over long years of working as a civil servant and researcher, not into a scientific report, but rather into a romantic novel of passion and suffering that would resonate with the many readers who would enjoy it. Saniee is one of those "new religious intellectuals--women and men--scholars and writers and journalists in Iran who were explicit about the feminist dimension of their work... and played a seminal role in the development of the new Islamic feminism." (Badran, 2011: 9) This Islamic feminism was generated as a type of feminism addressing Muslim women and the special characteristics of Muslim society, unlike Western discourse.

The Book of Fate is a winner of the Boccaccio Prize in Italy in 2013. It is a number one bestseller in many countries. The author gives voice to all the Iranian women who are victims and prisoners of domestic violence, tradition and men's abuses. Saniee's women are contemporary characters who struggle in order to get their lawful rights of well-being and survival despite the high price they have to pay. In an interview, Saniee has said: "They [women] have been largely the unsung heroines responsible for their own development as well as the progress and betterment of their families." (P. Saniee, Interview with Cristina Foarfa, Aug 19, 2013)

In the same interview, Saniee asserts that many female readers can see their own life stories in this novel. The novelist also asserts that she has included many social types with different socioeconomic and political backgrounds. Although the main protagonist, Massoumeh, is a fictional character, the events in the novel and her life experiences are quite realistic, reflecting the experience of women and men in similar societies and circumstances, which adds authenticity and universality to the work.

The following themes are quite dominant in the novel: family, forbidden love, adherence to social norms versus opting for romantic love, inequality between the two genders, revolution, ideological changes, and the victim/victimizer paradigm.

The writer attempts to portray the identity of the main female character through the depiction of personal life experiences. This is set against a historical-political background of pre- and post-Islamic Revolution in Iran (the era of the Shah's rule and the time after the Islamic Revolution until the present).

The richness of the novel is that while one is reading the personal story of a woman, one can also be reading about one's own life story, which can apply to thousands and millions of other people. All of this is made even more authentic and universal by the historical and political background, which affects and propels the characters and events. The novel will be examined as a social, realistic, and historical work of literature from a feminist point-of-view. 


\section{Analysis of The Book of Fate}

Massoumeh

But I went mad and screamed, "Why should He give me that fate?... Haven't I suffered enough? How long did I go from prison to prison, wash blood from my loved one's clothes, mourn, work day and night, and raise my children despite a thousand miseries? God, why do you keep testing me?" (Saniee, 2013: 365).

\subsection{Analysis overview}

The purpose of this paper is to examine how the woman novelist, Parinoush Saniee, has developed a bestselling feminist novel - The Book of Fate. The novel depicts the life journey of an Iranian Muslim girl/woman, Massoumeh, with all the challenges and abuses that can occur in a typical patriarchal, conservative, religious family and society. Patriarchy in this paper is defined as a system based on the superiority of men and consequently the subordination of the female gender, which leads to various forms of discrimination, oppression and unfairness.

The events of the novel span half a century of her life. During this period, there were great historical developments and changes in Iran, from the struggle against the Shah that culminated in the defeat of the Pahlavi empire and the victory of the Islamic Revolution led by Ayatollah Ruhollah Khomeini, the establishment of the Islamic Republic of Iran (1979), the ensuing the Iran-Iraq War (1980-88), and beyond.

The analysis will attempt to survey the major changes that the main protagonist undergoes, changing her from complete weakness and submissiveness in the face of patriarchal control, to a woman of strength and capabilities that will empower her to take care of her children and their welfare despite all financial, psychological, physical and societal challenges and mishaps.

The delineation of the individual in the novel under discussion also reflects the universal meaningfulness of its characterization of different character types, stereotypes and themes. Thus, the narrative not only echoes the "voiceless voice" of Massoumeh, but also that of many females who have similar experiences. The late Fadwa Tuqan, a prominent Palestinian feminist poetess, in her autobiography titled A Mountainous Journey (1984), expressed a similar notion of once being a voiceless female when she wrote,

I was unable to compose poetry; my inner voice was weak in protest against everything that had caused my silence... the corrupt laws and customs insisted that I remain secluded behind a wall, not able to attend assemblies of men... not participating in public life (Badran E Cooke, 2004: 27).

The novel depicts Iranian women's situation and difficulties related to the right of education, confinement or gender segregation, freedom of choice, unjust treatment, and their ability to confront obstacles in order to reach self-autonomy. Similar situations, to varying degrees, are likely to be found in other Oriental, religiously-governed and male-dominated societies. The novel sheds light as well on the changing political systems and how that affects people's lives.

What is the solution to these problems? How do such women act or react to face the familial and societal challenges of discrimination and lack of sympathy? What are the processes of transformation that can develop the woman's resilience and resourcefulness and change weakness to strength? In such a "game of power," can a woman, with all the imposed restrictions, generate strength despite her apparent weakness in order to overcome the grueling circumstances? How are all these questions reflected in a woman's fate as is depicted in The Book of Fate? 
The novel under analysis can be viewed as a bildungsroman, which follows the life journey of the main protagonist. "Bildung" means "education," and "roman" means "novel," i.e., a novel depicting the formation and education of an individual... a coming-of-age story. It is a literary genre that focuses on the psychological and moral growth of its protagonist from youth to adulthood (or the coming of age of a sensitive person who seeks answers to life's questions, expecting to gain experience of the world. Usually at the beginning of the story there is an emotional loss (in Massoumeh's case, this presents itself in her loss of her love, Saiid, and her forced marriage to Hamid). This makes the protagonist leave on his/her journey. (Wikipedia Contributors, 2020)

The main objective of this type of novel is to show the maturity of the main character, which is reached by passing through grueling difficulties and conflicts between the protagonist and the society. Gradually, the character will succumb to society's values and reappear later as more mature and aware, which can be a reflection of the Blakean Romantic philosophy of "innocence and experience." The loss of one's passive innocence through harsh experience in life is a celebration of human victory in awareness of maturity and adaptability. This itself is a triumphant achievement in the battle of survival in Massoumeh's life story.

Such novels usually depict the past of the protagonist in retrospect, which implies an adult perspective that has developed over the years. The popularity of this genre arises from the fact that many readers can identify with the character's experience. Such novels follow the main character's life from the early formative years to adulthood. In The Book of Fate, the events follow Massoumeh's life from adolescence, when she is only 16 years old, to being a wife and young mother, till her later stages of maturity as she becomes a widow and a middle-aged mother in her fifties. It is a journey that shows the attempt to adjust the personal desires of an individual to the general public dictates of society.

\subsection{Chronological analysis}

Massoumeh's nuclear family is composed of her father, mother, three brothers (Mahmoud, Ahmad and Ali), a younger sister (Faati), and herself. There is also reference to another sister, Zari, who died when she was eight years old, because the parents delayed calling for medical assistance, on the advice of the paternal grandmother who claimed that girls were survivors and not really worth the medical hassle!). Massoumeh's extended family is also evident in the presence and influence of grandparents, uncles, aunts, cousins, nephews, nieces and in-laws. Some friends and neighbors at times gain importance in the story and render acts of care, support and counseling more than do blood relatives.

The immediate family have just moved from Qum to settle in Tehran, the capital, at the outset of the novel. The reader is made aware that Qum follows stricter religious and social norms than those adhered to in Tehran. In Qum, the general attitude tended towards discouraging young females from going to school; they were expected to get married early in their teens. Greater restrictions were imposed, such as mandatory wearing of the hijab or chador, the full-body cloak wrapped around the head and body that is the traditional attire for Iranian women to wear when outside the house.

In Tehran, Massoumeh has to start her struggle against her fanatic brothers who are keen on keeping her from pursuing her school education. They prefer to marry her off as soon as possible, at the age of fifteen. They insist on her wearing the "chador". Massoumeh has to vigorously defend herself and convince her loving father to let her continue her education.

When we moved from Qum, father allowed me to continue going to school. Later, I told him, in Tehran girls don't wear chadors to school... he even let me wear a headscarf... I had to promise to be careful and not to bring shame by becoming corrupt and spoiled... I did know what I had to do to not bring him shame, even without wearing a chador and proper hijab (Saniee, 2013: 1).

Key words in this quote, such as "shame" "corrupted" and "spoiled" highlight society’s strict moral 
concerns. This is also a foreshadowing of coming events that will constitute the reason for Massoumeh's downfall in her adolescence.

From the beginning of the novel, the reader is made aware of the main characters 'concerns, the feminist and Islamic outlook of the young girl protagonist, and the family and social conditions and norms within which the characters and events play out. Massoumeh is at the center of events, pulled by two opposite forces: those against her freedom, chiefly her brothers, and others who show understanding and support for her, like her Uncle Abbas. She records her admiration for him as she has overheard him convincing her father, saying:

Brother! A girl has to be good from inside. It's not about proper hijab. Now that you have moved to Tehran, you have to live like Tehranis. The days when girls were locked up at home have passed. Let her go to school and let her dress like everyone else... (Saniee, 2013: 1-2).

Masoumeh has to struggle, employing various means to convince her father to allow her to resume her schooling, against the fierce resistance and disapproval of her brothers, and even of her own mother.

The adolescent Massoumeh then starts going to school every day accompanied by her friend, Parvaneh, who greatly influences her thinking and actions. Parvaneh is a personification of the feminist spirit of sisterhood, women's support to one another in order to counteract sexism. She facilitates the exchange of innocent love letters between Massoumeh and a young pharmacist. Later in life, Parvaneh will serve as a surrogate mother for Massoumeh's son.

During her two years of high school, Massoumeh proves to be an outstanding student. Parvaneh reports this academic success to her friend's mother, saying:

Today they returned our exam papers and Massoumeh got the highest grades.

Mother: What's the use, my girl? Those things are not practical for a girl.... She's wasting her time. Pretty soon she'll have to go to her husband's house and wash nappies.

Massoumeh: No, Mother, I'm not going to a husband's house any time soon. For now, I have to get my school diploma (Saniee, 2013: 27).

The mother's words are a reflection of the society's point-of-view regarding the education of girls. These words also prove to be prophetic, and so are Massoumeh's words which foretell of her future. Instances of submission and defeat of the female are to be followed by acts of resistance and overcoming in a game of power. Eventual accomplishments are gained through various tactics, employed by the young protagonist at that stage of her life.

Massoumeh is resourceful and capable of convincing her loving, tender-hearted father through techniques of crying, begging, convincing and reassuring, as has been previously mentioned. Her brothers are infuriated and object to her going to school. Ahmad is angry and wants to strangle her. He keeps finding excuses to beat her. And she keeps quiet. She is a voiceless female fighting in order to get her rights, even if her weapon is silence at that time. Her brother would follow her secretly to school, so she made sure that her chador is securely wrapped around her, covering her head and body. Here, she uses the typical traditional Islamic attire for an adult female as a means of resistance and protection to reach what she aspires to achieve. In this context, the chador serves as a positive agent for accomplishing what she aspires to. Although donning a veil can be looked upon as an oppressive act by some secular feminists,

for many Muslim women, wearing the veil has become a feminist act, serving as a symbol of their identity to countercultural imperialism. This is one example of how Muslim women are defining and developing feminism-on their own terms (Independent Lens, n.d.).

Unfortunately, her brother Ali finds out about her romance with Saiid, a young pharmacy assistant, and fires of hell are hurled at the innocent young girl. This will mark the tragedy of her life. 
She will suffer physically and psychologically; all her life, she will be made to pay the price for this social non-conformity.

Massoumeh suffers violent physical abuse at the hands of her brothers. She describes this, saying:

Ahmad lunged at me and struck me on my mouth with the back of his hand, so hard that my mouth filled with blood... Another blow landed under my eye and made me dizzy... Two consecutive slaps made my ear ring (Saniee, 2013: 43).

In such patriarchal societies, sometimes it is not only men who are abusive; women can also be abusive to other women. The young girl complains that her mother is either too busy with her younger siblings or watching over her brothers to give her older daughter the attention she needs. The mother devotes all of herself to Mahmoud, Ahmad and Ali, while Massoumeh is lost in the middle, vainly seeking love and affirmation of her self-worth. The negligent mother rarely shows sympathy or support to her daughter. Instead, she abuses her physically and verbally, as when she prays out loud that her daughter should suffer and be torn to pieces because of the shame she has brought to her family's honor: "May God strike you with diphtheria... O God, save me! To whom can I turn? Girl, I pray you get torn to pieces." (Saniee, 2013: 43) Significantly, the name, Massoumeh, is symbolic. In Farsi, it is an adjective that means "sinless and innocent." To her abusive family members, that meaning is starkly ironic.

Ahmad accuses his sister of creating a scandal that will destroy their family honor. Massoumeh attempts to defend herself by reminding them that he is the one who should be accused of smearing their honor: "Scandal? Is it I who caused a scandal, or is it you, coming home drunk every night and carrying on with a married woman? (Saniee, 2013: 43). The young girl is referring to Parvin, their neighbor who is a married woman. In the course of the novel, she will be revealed as a parallel case of victimization due to an abusive marriage and unfair social practices. Ironically, Parvin will become a friend and a great support to the young protagonist.

Massoumeh's brother abuses her both verbally and physically: '"Shut up or I'll hit you so hard on the mouth that your teeth will fall out! Mother, do you see how impudent she's become?" Ali clawed at my hair and dragged me into the house" (Saniee, 2013: 42). The mother is conditioned to take the side of the male members of the family. She calls her daughter "a tramp" and accuses her of flirting with a stranger in public. Massoumeh again tries to defend herself, saying: "Which stranger? My [fractured] ankle ached; the doctor at the pharmacy examined it and gave me some medicine... I was in pain, besides, in Islam a doctor is not considered a stranger" (Saniee, 2013: 42).

Massoumeh's accusation hurled at Ahmad, in her attempt at self-defense, is about two religiously condemned acts in Islamic doctrines, namely against consuming alcoholic drinks and adultery. But societal hypocrisy and double standards allow men to do what they wish while condemning female behavior for the slightest deviation from social expectations. Women are penalized severely in cases of moral and social violations. Margo Badran comments on the issue of family honor, saying: "Women's honor and honor of their families have been connected with women's actual and perceived adherence to moral norms. Men stray from that without losing their honor" (Badran, 2011: 310). Here, the saying in reference to the patriarchal society's double standard-"he's a stud, and she's a slut"--comes to mind.

Massoumeh is insulted, beaten up, stopped from going to school, and virtually imprisoned at home, not even allowed to meet or talk to her friend, Parvaneh. Moreover, the family decides to marry her hastily to the first suitor that proposes to her. Massoumeh attempts to commit suicide, but fails. She has no way to resist her fate, so she surrenders. She throws away the razor that was meant to kill her, and yields to her fate. This illustrates one of the significances of the title, The Book of Fate.

The young girl uses an analogy derived from fairy tales when she compares the marriage her family is planning to the act of fattening up a beautiful maiden in order to throw her to a ghoul (monster) to be devoured. She is only given his photograph to look at before she actually gets married to him! She takes solace in praying to God. She cries and wishes she were a boy so she would not suffer, and even prays to fall very sick and die like her late sister, Zari. Massoumeh throws herself at her 
mother's feet, begging her not to go ahead with the marriage. But her mother threatens her that her brother Ahmad, who is now always carrying a knife, is ready to cut her to pieces if she does not comply with the marriage. The young protagonist laments, saying that everyone had a say in her marriage, except for her. Being a female in such a male-dominated setup, she is denied her right of free choice. This adds up to the physical and mental abuse to which the girl/woman is subjected.

Massoumeh marries Hamid, who is not a bad person, but it turns out that he is a leftist activist and dissident in an underground group plotting against the Shah's regime. Not his personality, but his ideology and lifestyle will prove to be quite challenging for his young wife. He is well-educated, goodlooking and kind, but he doesn't want his wife to know about or interfere with his secret political endeavors, of which Massoumeh is totally unaware. This in itself constitutes a dismissive attitude towards her as she is neglected, considered insignificant and almost non-existent. It is a sexist and belittling attitude towards her basic human and emotional needs in the framework of marital rights. However, from an opposite point-of-view, one can perceive his attitude as being protective of his wife, trying to spare her the risks of involvement with his underground group.

From a feminist point-of-view, a hypothetical question can be raised: If the wife had such a cause to fight for, would she have been allowed to ignore her marital duties towards her spouse? Could he have been asked to keep silent and accepting?

Early on, Hamid's frequent absences from home force Massoumeh to learn to depend on herself completely. This helps awaken and nourish her potential strength, although it is still masked by a veil of weakness and helpless submission at times.

Though raised in a patriarchal society, Hamid is not a stereotypical abusive husband. He might even be considered the victim of a hasty marriage that was imposed on him. The marriage is orchestrated by his pious parents, who wished to go on the lifetime-longed-for Haj (holy pilgrimage) to Mecca. But they feel they should first discharge their parental obligations towards their son by arranging his marriage to a decent young bride, since "getting married is the completion of half of one's religion" as the Prophet (peace be upon him) says in a hadith. (The Hadith is a collection of traditions, containing the sayings of the Prophet Mohammad, which, along with accounts of his daily practice, the Sunna, constitute the major source of guidance for Muslims, apart from the Quran.) A similar hadith of the Prophet Mohammad says, "O young men, whoever among you can afford it, let him get married, for it is more effective in lowering the gaze and guarding chastity."

Hamid, like Massoumeh, has to be satisfied with seeing a picture of their future matrimonial partner; they do not meet each other in person prior to the marriage, which is not uncommon in a conventional arranged marriage. The marriage is unfair to both partners, since Hamid is much more committed to his ideological cause and political striving than he is to a normal married life and its obligations which he does not wish to embrace. His dedication to his dissident group will cause his imprisonment twice, once under the Shah's rule and then under the Islamic Republic. His eventual execution leaves Massoumeh a young widow with three children, who must face all sorts of ordeals and unfairness alone. Massoumeh and the children will suffer because of Hamid's negligence and absence, although he does not deliberately intend to hurt them.

Nonetheless, the marriage initially provides Massoumeh with the solace of a quiet, private home away from her abusive family. It gives her a mission and dedication in life. Hamid has many books that Massoumeh reads and makes use of in her cultural and educational growth. He encourages her to resume her education, which definitely proves to be a life-saver in the survival of their nuclear family as it allows her to become financially independent. Their three children, the offspring of their marriage, constitute everything in Massoumeh's life, even more so when she becomes a widow and a single mother. They are her reason for living and the meaning of her life.

Hamid never consciously abuses Massoumeh, but a form of abuse enters the picture through his friends, in a dramatic incident when she attempts to normalize her relationship with them. She takes the initiative to invite them to an elaborate dinner that she has carefully prepared to impress them. But when she excuses herself to perform one of the five daily prayers, this elicits the communist friends' laughter and ridicule. She answers their provocative queries as to why she has to pray by saying 
something that reflects Muslim consciousness: "Because I am a Muslim and every Muslim must pray. It is God's command." (Saniee, 2013: 128) Following that emotionally charged confrontation, Massoumeh goes to her room and suffers a miscarriage probably triggered by her great emotional agitation after the heated ideological discussion she has had with her husband's associates.

The thorny issue of religion and religious adherence seems to be constantly shaping events and characters in the novel. There is a sharp contrast between the fanatically religious, like Mahmoud, Massoumeh's brother, and the non-religious, like Hamid and his communist associates. It is noteworthy that Massoumeh is victimized by both of these extreme, non-moderate attitudes. Religion is a crucial formative factor in the life of these characters as it dramatically affects their social practices and political actions and reactions.

Eventually, Massoumeh has three children: two sons called Siamak and Massoud, and a daughter, Shirin. Now the events in the novel shed light on her new role as the dedicated, resilient and resourceful mother who spares no effort or opportunity to provide her children with the best upbringing and life that she can afford. Having continued her education, she is able to find a job that enables her to meet household expenses and her children's needs, something Hamid cannot do, because of his repeated absences and imprisonment.

This journey of life continues over many decades, filled more by pain and suffering than by fleeting moments of pleasure. People change and so do circumstances, influenced by different historical and political developments from the pre-Revolution to post-Revolution era. Our main protagonist, against such a turbulent background, has suffered a forced marriage, the forced situation of being a single mother during her husband's absences, and finally being a widow of a political prisoner. Hamid is executed during his second imprisonment term as a dissident and enemy of the Islamic political system.

Hamid dies shortly before his father's death. Consequently, his aunts and uncles inherit the father's house in which Massoumeh and her children have been living. The house has to be sold, and Massoumeh finds herself homeless, widowed, fired from her job, because of her husband's political stance, and unable to provide for her small family alone. Massoumeh describes her anguish over this situation, saying:

I spoke to myself like a mad woman. ...without a job, without Hamid, without his father, without home, without any inheritance, and with the stamp on my forehead identifying me as the widow of an executed communist, how was I going to save my children from the stormy sea and deliver them to safety? (Saniee, 2013: 308).

The young widow adapts to her new circumstances, stays with her children in a small annex in her in-law's house, and continues to work to support herself and her youngsters till she ensures their wellbeing as grown-ups. New challenges arise as Massoumeh is still considered the widow of a communist and the mother of a mujahed, the (Farsi and Arabic) term for a Muslim struggler striving in the cause of God. Siamak is briefly put into prison at a young age, accused of suspicious religiouspolitical activities. She will find out later that her own religiously fanatic brother, Mahmoud, is the one who informed on his own nephew. As a result, Siamak will not be able to continue his studies in Iran.

Again, the dedicated mother proves to be quite resourceful, managing to raise a considerable sum of money which she uses to help her eldest son escape to a neighboring country. Siamak then flies to Germany, where Parvaneh takes him under her wing; he finds the security provided to immigrants and is able to continue his education. He succeeds in establishing a new life for himself. Credit goes to Massoumeh for exerting tremendous, altruistic efforts to provide for her son's expenses and education in Germany, and for having taken the great risk of sending him there illegally. This can be considered as another form of resistance in her life journey for survival. She heroically sacrifices and fights to assist her loved ones to live a better life, even if that requires her own suffering.

In Germany, Siamak is embraced and supported by Parvaneh, Massoumeh's life-long friend. She looks after him, playing the role of caring mother, as well as continuing to assist Massoumeh, in a 
brilliant demonstration of sisterhood. Siamak graduates as an engineer, marries Parvaneh's daughter, and remains living abroad.

The second son, Massoud, is drafted and does his military service as a soldier fighting in the IraqIran war. After he is declared "missing in action," his mother has to fight against all odds to find out if he is alive or killed in battle. Expending incredible efforts, Massoumeh at last finds Massoud. He is brought home seriously wounded, but alive. Massoumeh nurses him till he miraculously recovers. He then resumes his university studies and graduates. He gets engaged and marries the daughter of an Ayatollah, a high-ranking man of religion in Iran, an authority in Islamic studies.

Shirin is the only daughter and the youngest. Massoumeh is always there for her daughter, who gets engaged to a young man that she loves. The young couple plan to live in Canada, where the young man works. Massoumeh urges Shirin to finish her university studies and obtain her B.A. degree before committing to marriage. By now, she has learned the lesson from her own personal experience of how vital education is for a female. This same message has been reiterated by many scholars, such as Qasim Amin in his book, The Liberation of Women (1899) and by many other feminist scholars beginning in the $19^{\text {th }}$ century. Massoumeh advises Shirin: "Study with peace of mind, start working, and stand on your own two feet so you don 't end up browbeaten, with your hands tied, and forced to accept humiliation" (Saniee, 2013: 405). Shirin reassures her that she is determined to get her university degree before her future marriage.

Massoumeh has done all she could to facilitate the lives and marriages of her children. She expresses her satisfaction, saying:

I felt that in spite of the hardships, I had met my responsibilities. My children had studied well, started their own lives and were successful. But I also felt empty and purposeless, just as I used to feel right after the final exams at school. It seemed there was nothing left for me to do (Saniee, 2013: 407).

Here, toward the end of the novel, the plot takes an unexpected turn. Saiid, Massoumeh's early love, reappears in her life. Their love is rekindled, and he proposes to her. A complete transformation has dawned on the protagonist. She becomes emotionally fulfilled, psychologically happy, and even her outer physical appearance becomes more youthful and radiant. But her "book of fate" and destiny will not allow those fleeting, amorous moments of contentment to last.

Ironically, her grown-up children, for whom she has sacrificed altruistically all her life, refuse adamantly and egotistically to give their consent to the marriage. In this respect, they are echoing the dictates of society and its unfair expectations. The idea of a second marriage for a widow is totally rejected, being regarded as a disgrace to the family. Consequently, Massoumeh turns down Saiid's proposal, the last spark of hope for happiness. Saiid laments her final decision to sacrifice their dream of love for the sake of appeasing her children's selfish demands. Saiid says:

But Massoumeh, in this way we will be lost to each other again.

Massoumeh: I know, I feel like committing suicide, and it is not my first time... But do you know what is most devastating?

"No!" (Saiid)

Massoumeh: The fact that both times it was my loved ones who contrived this kind of death for me (Saniee, 2013: 446-447).

Even in her surrender to "fate," Massoumeh is not a loser. This final act is not total surrender but rather a declaration of some freedom of choice on the woman's part. She chooses to sacrifice her emotional attachment to her beloved Saiid for the sake of preserving her relationship with her children. Her choice is also in accordance with social customs and traditions, which view a widow's remarriage as a kind of taboo, even though there is no religious prohibition against it. This decision is an assertion of self-autonomy and a declaration that her offspring constitute her entire life and wellbeing. In her final decision, Massoumeh has kept herself intact. 


\section{Feminist and Islamic feminist features in The Book of Fate}

O mankind, indeed We have created you from male and female and made you peoples and tribes that you may know one another. Indeed, the most noble of you in the sight of Allah is the most righteous of you. Indeed, Allah is Knowing and Acquainted. (Aya 13, Sura 49 (Al Hujarat, Qur'an).

In their laudable argument of equity between the two genders, Islamic feminists can rely on some Quran verses like the one above. Thus, all human beings-men and women--are equal; only taqwa or piety varies from one to the other.

The Book of Fate can be considered a voice of a once voiceless woman who, like many other females, suffers because of inequality between men and women. Most recent views consider writing about the domestic sphere as a laudable expression of self-autonomy. The ultimate aim at times of such transparency is to expose injustice done and suffered in order to develop awareness and eventually reform the unfavorable conditions imposed by society on women. The novel is a critique of biased family norms that victimize girls and women in particular.

Miriam Cooke has defined the term, feminist, as follows: "I use 'feminist' to refer to women who think and do something about changing expectations for women's social roles and responsibilities" (Cooke, 2001: iv).

Feminism is an attempt at making patriarchal societies aware of gender discrimination, and promoting measures to alter or dispense with such attitudes. The aim is to enable women to better flourish and make achievements in their societies, not only within the confines of the household, but also outside the limited sphere of the domestic domain, if required or desired. This empowerment of women is a result of education and work opportunities to better support themselves and their families, as is the case of Masoumeh, the main female protagonist in The Book of Fate.

Then, what is Islamic feminism in reference to the novel under discussion? Islamic feminism is "a feminist discourse and practice articulated within an Islamic paradigm... [It] derives its understanding... from the Qur'an, seeks rights and justice for women, and for men, in the totality of their existence," as is referred to in the above quoted Qur'anic verse (Badran, 2011: 242).

The right to basic and higher education was not always accessible to girls. Education has opened new horizons for women in general. The feminist demands for women's rights to education, employment, voting and holding political office were of paramount importance for women, especially in patriarchal societies.

Many scholars have contributed to such feminist awareness. Among these is Zainab Fawaz (186o1914), whose novel, Husn al-'Awaqib, (Good Consequences, 1899) is considered the first novel in Arabic written by a woman. As early as the late $19^{\text {th }}$ century, she advocated for the necessity of women working outside of their houses. Qasim Amin shared a similar view concerning the right of women to work, especially those belonging to the poor classes or those who felt they needed to. Amin also had a clear view about the issue of "woman's purity," asserting that the seclusion of women in the harem, or home confinement, does not guarantee their proper behavior or purity. He rather stressed the importance of proper upbringing and education that would protect the welfare of women. A proper upbringing "is a type of upbringing (and education) that will itself become an impenetrable veil... protecting a woman from all forms of corruption" (Amin, 2005: 56). His ideas dovetail neatly with what Abbas, Massoumeh's fraternal uncle, says to her father in order to convince him to send her to school and to adopt more modern city practices. Amin stressed that chastity is of great importance to a woman, along with " $a$ mature mind, the ability to organize, experience in raising children, the ability to maintain a suitable home environment" (Amin, 2005: 57). These traits apply to Massoumeh as the embodiment of the new woman.

Bahithat Al-Badiya (the pen name of Malak Hifni Nasif) (1886-1918), another pioneering, Egyptian, Muslim feminist scholar, expounded in a speech entitled "Women in Society" that motherly obligations did not require that a woman be confined or locked away in a house, and that a woman's work at home did not hinder her role in society. Within the domain of Islamic feminism, Bahithat Al- 
Badiya, like many others, rejected the assumption that women have only been responsible for their households and not created to be bread-winners. She was forced to stop her work as a teacher, as Egyptian law then forbade married women from teaching. She was shocked to find out, after her marriage, that her husband already had a wife and daughter that she was supposed to tutor.

The arguments stated above come as a defense of and support for women who share similar circumstances, like in Massoumeh's case. Women's "proper sphere" was, and is sometimes still, falsely believed, in certain patriarchal domains, to be domestic life, which focuses on housekeeping, childrearing and marital duties.

In a moment of feminist awakening, Massoumeh suddenly realizes that due to her husband's long, repeated absences, she has had to bear the full responsibility for her life. This awakening transforms her:

[F]inally on one beautiful May day, I reclaimed my ability to make decisions. I told myself that I was a mother and had responsibilities, that I had to be strong and stand on my own two feet, and that I had to raise my son in a happy, healthy environment. Everything changed. The joy of life flowed inside me (Saniee, 2013: 149).

Here the new strong-willed and determined Massoumeh is born out of the womb of suffering and discrimination. She is equipped with acceptance of her fate, her education, and assistance from relatives and women friends in the spirit of sisterhood, as propounded by feminist theories. These friends are namely Parvaneh, her lifelong friend; Parvin, a neighbor who acts as her personal advisor and caretaker of her and her children; and Shahrzad, a member of Hamid's underground communist group, who comes to stay at Massoumeh's house, seeking shelter and security. She helps Massoumeh see herself in a different positive light. When Massoumeh expresses her feelings of inferiority and jealousy of Shahrzad's capabilities and achievements, the latter reassures her by saying:

I am nobody, you are much better and more complete than me, too much a lady, a good and loving wife and a kind and wise mother, eager to read and learn, and willing to make sacrifices for your family (Saniee, 2013: 237).

Shahrzad's name can be seen as an allusion to the legendary female of the One Thousand- and One-Nights fairy tale. The "Shahrzadian" tradition relies on a woman seeking survival and victory over unfair male domination, who wins through perseverance, resilience and creativity.

Hamid, Massoumeh's husband, also acknowledges her transformation, saying: "You have changed so much! You seem mature and well-read. You sound like a philosopher, a psychologist. Did a few years of university change you this much? Massoumeh: No... Life's hardships forced me to change. I had to..." (Saniee, 2013: 272).

In many ways, Hamid is not exactly a model of the typical husband in a conservative, patriarchal society. He did not wish for Massoumeh to waste all her time cooking. He was also not in favor of her wearing a chador, which has been obligatory in Iran after the Islamic Revolution.

The veil or hijab is typical Islamic attire that distinguishes a Muslim woman in general; in Iran, it takes the form of the chador. Massoumeh adopts the chador and veil, as has been previously pointed out to meet social expectations and also to guarantee familial permission for her going to school. But she reassures her father that she can preserve her honor and chastity, not only by wearing the body veil.

This view seems to be in accordance with the opinions of the Islamic thinker, Al-Ghazali Harb, who towards the end of the 1970's, advocated what is called neo-Islamic modernism. Harb is a journalist and Al-Azhar University graduate. In his book, Istiqlal al mara'a fi al Islam (Woman's Independence in Islam), he calls for equality between men and women. He encourages the employment of women in order for them to achieve their personal, economic and financial independence. He asserts that a correct upbringing--not just the veil, is the proper protection for women. (Badran, 2011: 46) 
Islamic Feminism is "a feminist discourse and practice articulated within an Islamic paradigm... [It] derives its understanding and mandate from the Quran, seeks rights and justice for women, and for men, in the totality of their existence" (Badran, 2011: 242).

Such feminism is needed by Muslim women like Massoumeh, who want both Islamic practices and a feminist point-of-view which is not totally secular or Western. The main protagonist is born Muslim, believing in Islamic practices and ideology; thus, she does not accept the ideology of Hamid and his communist friends, which resulted in her becoming extremely upset to the point that she miscarries after their heated discussion, as has been alluded to.

Islamic is a qualifier describing a concept that pertains to Islamic practices and thought, and it can refer to some political points of view as well. Islamic feminism has gained its name and strength toward the end of the $2 \mathrm{O}^{\text {th }}$ century in different parts of the Middle East, especially early on in Iran and Egypt (Badran, 2011: 307).

The term Islamic Feminism, which began to be used and became prominent in the mid-199o's, is used to indicate a type of feminism and/or activity conducted by Muslim women who are seeking reform in social and legal practices which were forced on women in some Muslim societies.

By the time Islamic feminism surfaced as a phenomenon in the 1990's, there was a significant and rapidly growing literature in women's studies focusing on Muslim women and an expanding literature on Muslims' feminism... the work of "secular" women who were scholars [as is the case with Parinoush Saniee] in these fields helped bring to wider notice the emergent discourse of Islamic feminism generated by religious women or those who identified themselves with religion (Badran, 2011: 9).

Saniee's novel is a comment on society and the life of the women in it. The Book of Fate represents a different form of feminism which emerges from the middle class of society. Massoumeh is seen arguing against some conservative practices, and she defends herself until she can be somehow independent. The novel delineates a spectrum of women who are religious to varying degrees, but most of them are not conservative or fanatic.

The novel is a microcosm of a macrocosm swarming with different characters, both female and male. Since this analysis is done through a feminist lens, the focus is on women characters of different age brackets and in different situations, whose thoughts, words, actions and reactions have been put under inspection. Some of them matched the stereotypes of Muslim patriarchal society in their submission and devotion to men; while others did not. Some of them exhibited strength and resilience either openly or under the guise of a weak demeanor. Evidence of the feminist trait of sisterhood is to be found among the main strategies that helped the main character in her life. Massoumeh, as a young girl, fit the stereotype of an abused and subdued female. As an adult, however, she developed beyond this stereotype, helped by non-stereotypical characters like Parvaneh, Parvin, and others, including some non-stereotypical men, like her husband and uncle, and circumstances.

Stereotypes reflect beliefs and expectations about the characteristics or behaviors of most members of a social group. A stereotype can be a partially mistaken idea that many people have about a concept or a group which may be untrue or only partly valid.

In The Book of Fate, some men are not abusive towards women, but are rather supportive and appreciative. Among these are: Massoumeh's father initially, Hamid (sometimes), Uncle Abbas, and Uncle Hamid (her mother's brother). Uncle Hamid urges his sister, before he travels, not to be in a hurry to marry off her daughter before she finishes her education and becomes a mature lady. Massoumeh's father is not stereotypical at the outset of the novel, but later changes his supportive attitude towards his daughter, influenced by reports from family members, including not only his sons, but also his wife (Massoumeh's mother) and his mother. This grandmother is always to be heard talking unfavorably of girls, saying, for example: "Your girl has no [household] skills. When she gets married, they 'll send her back within a month...' She told father, why do you keep spending money on 
the girl? Girls are useless. They belong to someone else"' (Saniee, 2013:3). She even believes that girls do not merit special medical treatment as they, like cats with seven lives, do not die! Sadly, the unsympathetic beliefs of that grandmother result in the negligence and delay of required medical attention that caused the premature death of Zari, Masoumeh's sister. That misogynist grandmother favors sons and thinks of girls as a burden or source of potential disgrace to their families. This is not a totally unrealistic portrayal.

Massoumeh's mother, as a product of such a misogynist mentality, will do anything for her sons, even cover up for their misbehavior and moral deviations. On the other hand, she is negligent and abusive to Massoumeh, physically, verbally and psychologically. She collaborates with her sons to deprive her of her basic right to pursue her education and later usurps her free will by forcibly marrying her off. The mother is a woman who has helped ruin another woman's life. So, she is an example of the sisterhood or support that one female can give another. She and the grandmother rather fit the stereotype of female abusers in a patriarchal society, despite the fact that they are themselves women.

Massoumeh, as the main protagonist, is subjected to abuse by members of her family, both men and women. Both her mother and grandmother hurt her as has been discussed. On the other hand, other female characters greatly assist her in her life struggles, in an exhibition of fortitude and resilience among women.

Parvaneh, as a school friend and advisor, has not been passive or submissive. She is a character foil of Massoumeh. She is portrayed as liberated and strong; she could stand up as an equal to her brothers, fighting back if necessary, unlike Massoumeh who has been hurt the most by her brothers ' cruelty and interference in her life. Parvaneh plays the role of go-between for Massoumeh and Saiid, helping in their exchange of love letters. She also takes care of Siamak, Massoumeh's eldest son when he escapes to Germany.

Parvin is a female neighbor and friend to Massoumeh. Like Parvaneh, she is liberal and openminded, and not a stereotypical weak woman. Her life and marriage can be paralleled to Massoumeh's suffering and acceptance of an incompatible partner for the sake of survival. Parvin comes to the young Massoumeh's rescue in different instances: first, when she convinces her to marry Hamid, a more appropriate match than the disastrous ones suggested by her brothers; later, when Massoumeh was juggling between her children and job, Parvin was always there ready to baby-sit.

Shahrzad, Hamid's activist colleague, is far from being a stereotypical woman in a maledominated society. She lives and dies for the political cause in which she believes. She contributes to Massoumeh's realization of her own self-worth. She compliments her on her ability to successfully handle all the tasks allotted to her as a mother, wife, student and working woman. Shahrzad, like the one in the fairy tale, is a resourceful woman, struggling against injustice in a male-dominated world. Even when her life comes tragically to an end, she dies triumphantly fighting for her political cause.

The shift of power in Massoumeh's favor indicates the resilience and strength that Muslim women can acquire, as recognized by Massoumeh and her husband Hamid. Her transformation can be an inspiration to other women in similar circumstances. Massoumeh's life has been an inferno of suffering. This fire of suffering did not consume her as much as it polished the real gem inside of her. The marked transformation in Massoumeh can be basically attributed to her innate resourcefulness and strength, as well as the lessons she has learned through experience in life. In many cases, necessity forced her into resourcefulness. Her education has been a great facilitator for getting a job, and consequently she has been capable of supporting her family.

\section{Conclusion}

The present research paper has analyzed the novel, The Book of Fate, from various literary, social, historical and feminist points-of-view. Through this analysis, questions pertaining to how and why the woman protagonist and other women in similar circumstances are made to suffer and yet manage to survive, were clarified. The paper has surveyed why and how the girl/woman had to undergo numerous injustices. She has been abused physically, psychologically, emotionally, financially and intellectually 
in an unjust patriarchal and blindly conservative Oriental society. Such unfairness threatened to deprive her of her basic right to education and hurled her into a hasty, incompatible marriage to a total stranger, because of a brief, innocent romantic attraction. The rest of her life, which spans decades of suffering and resistance, reflects not only one individual lifetime, but that of many women. The personal life-story is delineated against the political, social and religious background which colored society in Iran.

In the present analysis, special emphasis has been given to Islamic feminist consciousness in an attempt to develop awareness which could lead to positive modifications of such unfair social norms and traditional and, allegedly, religious dictates.

In view of the numerous sacrifices and ordeals of the female protagonist, the final conclusion of the novel may be seen as ambivalent. In the light of the above analysis, however, it can be seen not as a result of weakness and surrender, but rather as an indication of a degree of inherent strength and resilience. It is not the final defeat of a woman, but rather a positive practice of free will. It is the voice of a woman who decides for herself. It is a final note, not of defeat, but of the willed surrender of a woman who embraces and finds peace in her "Book of Fate."

\section{Acknowledgement}

To Al-Balqa Applied University for granting me a sabbatical year that allowed me to do this paper. And to Sally Bland, Sary and Hashem ElAssad for their technical and editorial efforts.

\section{References}

Amin, Q. (2005). The liberation of women: The new woman (S. S. Peterson, Trans.). The American University in Cairo Press.

Badran, M. (2011). Feminism in Islam: Secular and religious convergences. Oneworld.

Badran, M., \& Cooke, M. (2004). Opening the gates: An anthology of Arab feminist writing. Indiana University Press. Independent Lens. (n.d.). Shadya: Muslim feminism. PBS. https://www.pbs.org/independentlens/shadya /muslimfeminism.html

Qur'an. (Sahih International).

Saniee, P. (n.d.). Sahme man (The book of fate). The Susijn Agency Ltd. http://www.the susijnagency.com/ParinoushSaniee.htm

Saniee, P. (Interview with Cristina Foarfa). "I wanted to introduce a generation of Iranian women...." http://www.bookaholic.ro/parinoush-saniee-i-wanted-to-introduce-a-generation-of-iranian-women-withall-the-difficulties-they-encounter-interview.html.

Wikipedia Contributors. (n.d.). Bildungsroman. Wikipedia, the free encyclopedia. Retrieved July 04, 2019, from https://en.wikipedia.org/wiki/Bildgunsroman 